\title{
Lipid peroxidative stress and antioxidant defence status during ontogeny of rainbow trout (Oncorhynchus mykiss)
}

\author{
Stéphanie Fontagné*, Emilie Lataillade, Janine Brèque and Sadasivam Kaushik \\ Unit of Nutrition, Aquaculture and Genomics NuAGe, Pôle d'Hydrobiologie INRA, Saint Pée-sur-Nivelle 64310, France \\ (Received 30 July 2007 - Revised 23 October 2007 - Accepted 30 October 2007 - First published online 6 December 2007)
}

The objective of the present study was to characterise some important antioxidant enzymes and their relationships with retinoids and lipid peroxidation during rainbow trout (Oncorhynchus mykiss) early development. Eggs were incubated at $7^{\circ} \mathrm{C}$ until the swim-up stage whereupon fry were fed two semi-purified diets with $0 \%(\mathrm{CO})$ and $8 \%(\mathrm{OX})$ oxidised lipid respectively for 2 months at $17^{\circ} \mathrm{C}$. The activities and gene expression of superoxide dismutase (SOD), catalase (CAT) and glutathione peroxidase (GPX) were determined as well as the levels of retinoids, F2-isoprostanes and lipid-soluble fluorescent products (LSFP) at various developmental stages. Only SOD had a detectable activity in embryos which increased during development and was linked with an increase of mitochondrial (SOD2) and cytosolic (SOD1) gene expression. SOD1 and SOD2 mRNA were more abundant in fry fed OX than in fry fed CO. CAT activity and gene expression also increased during development and were higher in fry fed OX compared with fry fed CO. Activity of Se-dependent GPX (Se-GPX) increased during development. The gene expression of cytosolic Se-GPX (GPX1) increased from hatching to 2-month-fed fry. Both phospholipid-hydroperoxide GPX and GPX1 genes were more expressed in fry fed OX than in fry fed CO. Retinoids decreased during development and, by 2 months, were lowered in fry fed OX compared with those fed CO. The levels of LSFP were higher in fry fed OX compared with fry fed CO. The present study demonstrates that antioxidant defence systems are active all through the development of rainbow trout and modulated by feeding oxidised lipid.

Rainbow trout: Larval development: Lipid peroxidation: Antioxidant enzymes

Under physiological conditions, aerobic tissues continuously generate reactive oxygen species as a byproduct of oxidative metabolism $^{(1)}$. In some specific cell types, reactive oxygen species generation may be beneficial against a pathogen. However, in most cases, high amounts of reactive oxygen species are harmful to cells and cause DNA damage, enzyme inactivation and structural protein degradation as well as peroxidation of PUFA leading to pathologies and alteration of development ${ }^{(2)}$. As fish contain high concentrations of highly unsaturated fatty acids, they are vulnerable to lipid peroxidation and to tissue damage resulting from lipid peroxidation ${ }^{(3)}$. Pathology related to oxidative stress in fish includes reduced growth, poor survival, liver degeneration, anaemia and muscular dystrophy ${ }^{(4-6)}$. Oxidative stress is due to the overwhelming of antioxidant defences of cells by pro-oxidants. This imbalance can be aggravated by diet composition. Feeds for fish and especially feeds for fish larvae contain high levels of PUFA derived from marine fish oils and meals. These fatty acids are particularly prone to oxidative damage during diet preparation and storage. Products derived from lipid peroxidation may be absorbed and transported to tissues, where they may induce oxidative stress $^{(7)}$.
To decrease reactive oxygen species levels and avoid lipid peroxidation, all aerobic organisms possess two types of antioxidant defence systems. One is represented by enzymes and includes superoxide dismutase (SOD), catalase (CAT) and glutathione peroxidase (GPX). SOD is a metalloenzyme that catalyses the dismutation of the superoxide anion $\left(\mathrm{O}_{2}^{-}\right)$ into oxygen and $\mathrm{H}_{2} \mathrm{O}_{2}{ }^{\left({ }^{8}\right)}$. The $\mathrm{Cu} / \mathrm{Zn}-\mathrm{SOD}$ is located in the cytosol and nucleus, while Mn-SOD is localised within the mitochondrial matrix. Subsequently, $\mathrm{H}_{2} \mathrm{O}_{2}$ is reduced to water by CAT in the peroxisomes. GPX catalyses the same reaction as CAT in the cytosol and also converts lipid hydroperoxides into lipid hydroxides, which are more stable products. The other group of antioxidant defence systems is composed of free radical scavengers. These compounds, generally of low molecular weight, lipid or water soluble, are mainly represented by vitamins $\mathrm{E}$ and C. However, vitamin A has also been shown to reduce lipid peroxidation ${ }^{(9)}$. If the antioxidant actions of vitamins $\mathrm{E}$ and $\mathrm{C}$ are well known, the antioxidant action of vitamin A remains still unclear. It could be due to the ability of the free alcohol form of vitamin A to quench singlet oxygen $^{(10)}$ or to the ability of retinoic acid to increase expression and activity of antioxidant enzymes ${ }^{(11)}$. Moreover,

Abbreviations: CAT, catalase; CO, semi-purified diet with $0 \%$ oxidised lipid; CT, cycle threshold; dpf, days post-fertilisation; EF1 $\alpha$, elongation factor $1 \alpha$; GPX, glutathione peroxidase; HPGPX, phospholipid-hydroperoxide glutathione peroxidase; LSFP, lipid-soluble fluorescent products; OX, semi-purified diet with $8 \%$ oxidised lipid; Se-GPX, Se-dependent glutathione peroxidase; SOD, superoxide dismutase.

* Corresponding author: Dr Stephanie Fontagné, fax +33 559545152, email fontagne@st-pee.inra.fr 
vitamin A has many other functions that are more prominent than its activity as an antioxidant especially during early development ${ }^{(12)}$.

The objective of the present study was hence to characterise some important antioxidant enzymes and their relationships with retinoids and lipid peroxidation during rainbow trout (Oncorhynchus mykiss) early development. The response of antioxidant defence systems to dietary pro-oxidant conditions was also evaluated by feeding fry with oxidised lipid.

\section{Materials and methods}

\section{Experimental fish and diets}

Rainbow trout (O. mykiss) eggs were obtained from fertilisation of ova collected from eight females by a common pool of sperm from eight males in the INRA experimental fish farm in Lées-Athas (Pyrénées-Atlantiques, France). Eggs were incubated in a large tray supplied by spring water at $7 \pm 1^{\circ} \mathrm{C}$. At the eyed stage ( $32 \mathrm{~d}$ post-fertilisation (dpf)) and hatching ( $44 \mathrm{dpf}$ ), dead embryos were removed. At the swim-up stage $(70 \mathrm{dpf})$, fry were transferred to the INRA experimental fish farm in Donzacq (Landes, France) and randomly distributed into six tanks (600 larvae per 50 litre fibreglass tank) supplied by spring water at $17 \pm 1^{\circ} \mathrm{C}$. From the swim-up stage, which corresponds to the beginning of exogenous feeding, fish were hand-fed four or six times per d to apparent satiation. Two semi-purified diets with $0 \%(\mathrm{CO})$ and $8 \%(\mathrm{OX})$ oxidised lipid respectively were tested in triplicate for 2 months (Table 1). Diets were isoproteic (56\%) and

Table 1. Formulation and composition of experimental diets (g/100 g dry weight)

\begin{tabular}{|c|c|c|}
\hline Diet & $\mathrm{CO}$ & OX \\
\hline \multicolumn{3}{|l|}{ Ingredients } \\
\hline Casein-dextrin basis* & $75 \cdot 0$ & $75 \cdot 0$ \\
\hline Soyabean lecithin† & 8.0 & $8 \cdot 0$ \\
\hline Fresh salmon oil & $8 \cdot 0$ & - \\
\hline Oxidised salmon oil & - & $8 \cdot 0$ \\
\hline Mineral mixture & 4.5 & 4.5 \\
\hline Vitamin mixture§ & 4.5 & 4.5 \\
\hline \multicolumn{3}{|l|}{ Proximate composition } \\
\hline DM (\%) & 93.6 & $92 \cdot 7$ \\
\hline Crude protein & $49 \cdot 3$ & $49 \cdot 5$ \\
\hline Total lipids & $16 \cdot 0$ & $15 \cdot 8$ \\
\hline Ash & $6 \cdot 1$ & 6.5 \\
\hline Gross energy (kJ/g DM) & $22 \cdot 7$ & $22 \cdot 6$ \\
\hline
\end{tabular}

CO, semi-purified diet with $0 \%$ oxidised lipid; OX, semi-purified diet with $8 \%$ oxidised lipid.

*Casein-dextrin basis (\% diet): $35 \%$ casein (VWR Prolabo 22544.292; Fontenay-sous-Bois, France); $10.5 \%$ casein Na salt (Sigma C8654); $5 \%$ casein hydrolysate (Sigma C0626); 0.6\% D,L-methionine (Ajinomoto Eurolysine); $0.8 \%$ L-arginine $\mathrm{HCl}$ (Ajinomoto Eurolysine); $23.1 \%$ dextrin (Sigma D2256).

† Louis François, St Maur des Fossés, France.

¥ Mineral mixture ( $\mathrm{g} / \mathrm{kg}$ mineral mix): $\mathrm{KCl}, 90 ; \mathrm{KI}, 0.04 ; \mathrm{CaHPO}_{4} \cdot 2 \mathrm{H}_{2} \mathrm{O}, 500$; $\mathrm{NaCl}, 40 ; \mathrm{CuSO}_{4} \cdot 5 \mathrm{H}_{2} \mathrm{O}, 3 ; \mathrm{ZnSO}_{4} \cdot 7 \mathrm{H}_{2} \mathrm{O}, 4 ; \mathrm{CoSO}_{4}, 0.02 ; \mathrm{FeSO}_{4} \cdot 7 \mathrm{H}_{2} \mathrm{O}$, 20; $\mathrm{MnSO}_{4} \cdot \mathrm{H}_{2} \mathrm{O}, 3 ; \mathrm{CaCO}_{3}, 215 ; \mathrm{MgOH}, 124 ; \mathrm{Na}_{2} \mathrm{SeO}_{3}, 0.03 ; \mathrm{NaF}, 1$.

$\S$ Vitamin mixture (per $\mathrm{kg}$ vitamin mix): retinyl acetate, $150.15 \mathrm{mg}$ retinol equivalent (500 $000 \mathrm{IU})$; cholecalciferol, $6.25 \mathrm{mg}(250000 \mathrm{IU})$; DL- $\alpha$-tocopheryl acetate, $5 \mathrm{~g}$; menadione, $1 \mathrm{~g}$; thiamin $-\mathrm{HCl}, 0.1 \mathrm{~g}$; riboflavin, $0.4 \mathrm{~g}$; $\mathrm{D}$-calcium panthothenate, $2 \mathrm{~g}$; pyridoxine $-\mathrm{HCl}, 0.3 \mathrm{~g}$; cyanocobalamin, $1 \mathrm{mg}$; niacin, $1 \mathrm{~g}$; choline, $100 \mathrm{~g}$; ascorbic acid (L-ascorbyl-2-polyphosphate), $5 \mathrm{~g}$; folic acid, $0.1 \mathrm{~g}$; D-biotin, $20 \mathrm{mg}$; meso-inositol, $30 \mathrm{~g}$. All ingredients were diluted with $\alpha$-cellulose. isolipidic (16\%) with $8 \%$ soyabean lecithin and $8 \%$ fresh or oxidised salmon oil. Oxidised lipid was obtained by bubbling air through fish oil (La Lorientaise, France; specially prepared from crude salmon oil, additive free) for $90 \mathrm{~h}$ at $50^{\circ} \mathrm{C}$. Fresh and oxidised oils were stabilised immediately after reception or oxidation with 300 parts per million ethoxyquin as in common usage for fish oil for animal nutrition, resulting in a final concentration of 24 parts per million ethoxyquin in diets, in order to spare the other nutrients such as vitamins and test only the effect of oxidised lipid and not of oxidised diet. Oils were both assayed for oxidative state before incorporation into the diets (Table 2).

\section{Chemical analyses of diets and oils}

Proximate composition of diets was determined according to the following procedures: $\mathrm{DM}$ after drying at $105^{\circ} \mathrm{C}$ for $24 \mathrm{~h}$, protein $(\mathrm{N} \times 6.25)$ by the Kjeldahl method after acid digestion, ash by incineration at $550^{\circ} \mathrm{C}$ for $16 \mathrm{~h}$ and gross energy in an adiabatic bomb calorimeter. Total lipid was extracted and measured gravimetrically according to Folch et al. ${ }^{(13)}$ using dichloromethane instead of chloroform. Fatty acid methyl esters were prepared by acid-catalysed transmethylation of total lipids according to Shantha \& Ackman $^{(14)}$ and analysed in a Varian Chrompack CP-3800 gas chromatograph equipped with a DB Wax fused silica capillary column $(30 \mathrm{~m} \times 0.25 \mathrm{~mm}$ internal diameter, film thickness $0.25 \mathrm{~mm}$; Varian, Les Ulis, France) using $\mathrm{He}$ as the carrier gas $(1.4 \mathrm{ml} / \mathrm{min})$. The thermal gradient was 100 to $180^{\circ} \mathrm{C}$ at $8^{\circ} \mathrm{C} / \mathrm{min}, 180$ to $220^{\circ} \mathrm{C}$ at $4^{\circ} \mathrm{C} / \mathrm{min}$ and a constant temperature of $220^{\circ} \mathrm{C}$ during $20 \mathrm{~min}$. Injector and flame ionisation detector temperatures were 260 and $250^{\circ} \mathrm{C}$, respectively. The unsaturation index (UI) was calculated according to the formula: $\mathrm{UI}=$ sum $($ fatty acid percentage) $\times$ (number of double bonds). Peroxide value of fish oil was determined by colorimetric determination of Fe-thiocyanate according to Shantha \& Decker ${ }^{(15)}$. Conjugated dienes and trienes were measured as specific extinctions at the wavelengths of 232 and $268 \mathrm{~nm}$, respectively ${ }^{(16)}$. Anisidine value was determined according to the European Committee for Standardization ${ }^{(17)}$. Thiobarbituric acid-reactive substances were measured according to Salih et al. ${ }^{(18)}$ with modifications. Briefly, samples were homogenised in $20 \%$ TCA (w/v) containing $0.02 \%$ of butylated hydroxytoluene as antioxidant using ultra-turrax and centrifuged at $5000 \mathrm{~g}$ for $20 \mathrm{~min}$ at $4^{\circ} \mathrm{C}$. The resulting supernatant fractions were incubated with $0.8 \%$ thiobarbituric acid solution (w/v) at $100^{\circ} \mathrm{C}$ for $30 \mathrm{~min}$, cooled in ice and centrifuged at $800 \mathrm{~g}$ for $10 \mathrm{~min}$. Absorbance was measured at $532 \mathrm{~nm}$ and the quantification was achieved by comparison with a standard curve of malondialdehyde equivalents generated by acid-catalysed hydrolysis of 1,1,3,3-tetraethoxypropane.

\section{Sample collection}

Samples were taken on 0, 21, 44 and $70 \mathrm{dpf}$ stages and from each tank on 81,98 and $133 \mathrm{dpf}$ stages after starvation for $24 \mathrm{~h}$. These stages correspond respectively to oocytes, embryos, hatched fry, swim-up fry, complete yolk-sac resorbed fry, 1-month-fed fry and 2-month-fed fry. Fish were anaesthetised 
Table 2. Oxidative status and fatty acid composition of crude salmon oil and experimental diets* (Mean values and standard deviations)

\begin{tabular}{|c|c|c|c|c|c|c|c|c|}
\hline & \multicolumn{4}{|c|}{ Salmon oil } & \multicolumn{4}{|c|}{ Diet } \\
\hline & \multicolumn{2}{|c|}{ Fresh } & \multicolumn{2}{|c|}{ Oxidised } & \multicolumn{2}{|c|}{$\mathrm{CO}$} & \multicolumn{2}{|c|}{ OX } \\
\hline \multicolumn{9}{|l|}{ Evaluation of lipid oxidation } \\
\hline Peroxide value (meq peroxides/kg) & $3 \cdot 3^{b}$ & 0.1 & $234 \cdot 6^{\mathrm{a}}$ & $2 \cdot 8$ & $0.11^{\mathrm{b}}$ & 0.00 & $0.32^{\mathrm{a}}$ & 0.00 \\
\hline Conjugated dienes (extinction at $232 \mathrm{~nm}$ ) & $11 \cdot 8^{b}$ & 0.1 & $22 \cdot 8^{\mathrm{a}}$ & 0.1 & $11 \cdot 1^{\mathrm{b}}$ & 0.1 & $18 \cdot 6^{\mathrm{a}}$ & 0.0 \\
\hline Anisidine value & $4 \cdot 6^{\mathrm{b}}$ & 0.0 & $179 \cdot 5^{\mathrm{a}}$ & $4 \cdot 1$ & $4 \cdot 5^{\mathrm{b}}$ & $1 \cdot 2$ & $26 \cdot 1^{\mathrm{a}}$ & $2 \cdot 4$ \\
\hline TBARS $(\mu \mathrm{mol} / \mathrm{kg})$ & $86^{b}$ & 12 & $920^{\mathrm{a}}$ & 91 & $29^{b}$ & 4 & $172^{\mathrm{a}}$ & 5 \\
\hline \multicolumn{9}{|l|}{ Fatty acid composition ( $\mathrm{g} / 100 \mathrm{~g}$ total fatty acids) } \\
\hline SFA & $29 \cdot 8$ & 0.4 & $31 \cdot 8$ & 0.8 & $28 \cdot 1$ & 0.5 & $30 \cdot 9$ & $1 \cdot 1$ \\
\hline Monoenes & $43 \cdot 8$ & 0.4 & $43 \cdot 8$ & 0.1 & $30 \cdot 6$ & 0.2 & $30 \cdot 3$ & 0.2 \\
\hline$n-6$ & $7 \cdot 6$ & 0.3 & $7 \cdot 7$ & 0.0 & $26 \cdot 7$ & 0.8 & $26 \cdot 0$ & 0.2 \\
\hline$n-3$ & $14 \cdot 5^{\mathrm{a}}$ & 0.1 & $11.9^{b}$ & 0.7 & $12 \cdot 4^{\mathrm{a}}$ & 0.1 & $9 \cdot 5^{\mathrm{b}}$ & 0.5 \\
\hline Unsaturation index & $139^{\mathrm{a}}$ & 0 & $126^{\mathrm{b}}$ & 3 & $149^{a}$ & 1 & $131^{\mathrm{b}}$ & 4 \\
\hline
\end{tabular}

CO, semi-purified diet with $0 \%$ oxidised lipid; OX, semi-purified diet with $8 \%$ oxidised lipid; TBARS, thiobarbituric acid-reactive substances.

* Two replicates for fatty acids, three replicates for peroxide value, conjugated dienes and trienes and anisidine value, or six replicates for TBARS.

${ }^{a, b}$ Mean values within a row and for each compound category (oil or diet) with unlike superscript letters are significantly different $(P<0.05)$.

in diluted 2-phenoxyethanol for wet weight determination, frozen in liquid $\mathrm{N}_{2}$ and stored at $-80^{\circ} \mathrm{C}$ until analysis.

\section{Determination of total 8-isoprostane levels and lipid-soluble} fluorescent products

The level of oxidative stress was assessed by measuring larval concentration of 8 -isoprostanes, the products of non-enzymic peroxidation of arachidonic acid by reactive oxygen species. Isoprostanes were assayed in all withdrawn samples except $21 \mathrm{~d}$ embryos (due to the small size of samples) by enzyme immunoassay (EIA) using the Cayman Chemical 8-isoprostane EIA kit (SPI-BIO, Massy, France) as previously described ${ }^{(19)}$.

For measurement of lipid-soluble fluorescent products (LSFP), total lipid of oocytes and fry from the swim-up stage onwards was extracted according to Folch et al. ${ }^{(13)}$ and diluted in chloroform-methanol $(7: 3, \mathrm{v} / \mathrm{v})$. Fluorescence intensity was determined in a spectrofluorometer Triad Dynex (Serlabo Technologies, Bonneuil sur Marne, France) using excitation/emission wavelengths of $360 / 465 \mathrm{~nm}$ and quinine sulfate was used as standard at a concentration of $1 \mu \mathrm{g} / \mathrm{ml}$ in $0.05 \mathrm{M}$-sulfuric acid.

\section{Determination of retinoid levels}

Retinoid extraction was conducted by homogenising $2.5 \mathrm{~g}$ of oocytes, swim-up fry, 1-month fry or 2-month fry in 10 volumes of $10 \mathrm{~mm}$-PBS. The homogenate was divided into two equivalent volumes (mixtures $\mathrm{A}$ and $\mathrm{B}$ ). The $\mathrm{pH}$ of mixture $\mathrm{B}$ was adjusted to 4.2 with acetic acid before sonication for $3 \mathrm{~min}$. Proteins were precipitated by adding $4.5 \mathrm{ml}$ ethanol containing $2 \%$ pyrogallol (w/v) as antioxidant. After addition of $10 \mathrm{ml}$ hexane (mixture A) or ethyl acetate-methyl acetate $(8: 1, \mathrm{v} / \mathrm{v})$ (mixture B), mixtures were centrifuged (10 min; $\left.10000 \mathrm{~g} ; 4^{\circ} \mathrm{C}\right)$. Samples were extracted two other times with $4 \mathrm{ml}$ hexane or ethyl acetate-methyl acetate $(8: 1, \mathrm{v} / \mathrm{v})$ and the upper organic phases were pooled for each mixture and evaporated to dryness under $\mathrm{N}_{2}$. The residues were then dissolved in $200 \mu \mathrm{l}$ isopropanol-methanol-acetonitrile-tetrahydrofuran (40:30:15:15, by vol.). After centrifugation at $10000 \mathrm{~g}$ for $3 \mathrm{~min}$, a $100 \mu \mathrm{l}$ sample was subjected to HPLC on a 2695 Alliance Separation Module equipped with a Waters 2487 dual $\lambda$ absorbance detector and a Waters 2475 multi-wavelength fluorescence detector (Waters, Saint-Quentin-en-Yvelines, France). Instrument control, and data acquisition and processing were achieved by the use of Waters Empower software.

Retinol and retinyl palmitate were determined by injection of mixture A into a Spherisorb ODS2 $\mathrm{C}_{18}$ reversed-phase column $(250 \times 4.6 \mathrm{~mm}$, with a particle size of $5 \mu \mathrm{m}$; Waters $)$ fitted with a security guard cartridge system. Retinoic acid and retinal were determined by injection of mixture $B$ into the same column. The solvent system consisted of wateracetonitrile-methanol (57:37:6, by vol.) containing $100 \mathrm{~mm}-$ ammonium acetate ( $\mathrm{pH} 4.2)$ (solvent A), methanol (100\%) (solvent B) and acetonitrile-methanol-isopropanol (60:35:5, by vol.) (solvent $\mathrm{C}$ ). A linear gradient from solvent $\mathrm{A}$ $(100 \%)$ to solvent B $(100 \%)$ was applied over a period of $20 \mathrm{~min}$, followed by isocratic elution with solvent B (100\%) for $5 \mathrm{~min}$ and isocratic elution with solvent $\mathrm{C}(100 \%)$ for $45 \mathrm{~min}$. Then a linear gradient from solvent $\mathrm{C}(100 \%)$ to solvent A $(100 \%)$ was applied for $5 \mathrm{~min}$. The flow rate was set at $1 \mathrm{ml} / \mathrm{min}$ and the detection wavelength at $350 \mathrm{~nm}$ for the detection of retinoic acid and retinal and $325 \mathrm{~nm}$ for the detection of retinol and retinyl palmitate. Retinoids were identified by retention times of pure standards (Sigma, Saint-Quentin-Fallavier, France).

\section{Determination of antioxidant enzyme activities}

The whole embryos or larvae samples were homogenised in 7 volumes of ice-cold 20 mM-phosphate buffer $(\mathrm{pH} \mathrm{7.4)}$ containing $1 \mathrm{mm-EDTA}$ using ultra-turrax. The homogenates were centrifuged at $1000 \mathrm{~g}$ for $10 \mathrm{~min}$ at $2^{\circ} \mathrm{C}$ to remove debris. The resultant supernatant fractions were incubated for $1 \mathrm{~h}$ with 0.2 volumes of $20 \mathrm{~mm}$-phosphate buffer $(\mathrm{pH} \mathrm{7.4)}$ containing 
$1 \mathrm{~mm}$-EDTA and $0.5 \%$ Triton X-100 (v/v) before use for antioxidant enzyme assays.

The activity of total SOD (EC 1.15.1.1) was assayed using a reagent kit and SOD from bovine liver as a standard (Sigma). The reaction was based on its inhibitory effect on the rate of superoxide-dependent reduction of a water-soluble tetrazolium salt (WST-1) by xanthine-xanthine oxidase ${ }^{(20)}$. The reaction was monitored at $450 \mathrm{~nm}$ and $37^{\circ} \mathrm{C}$. One SOD unit was defined as the amount of enzyme required to inhibit the reduction of WST-1 to WST-1 formazan in the presence of superoxide by $50 \%$.

CAT activity (EC 1.11.1.6) was assayed in a quartz microplate with $5 \mu \mathrm{l}$ sample solution in a final volume of $250 \mu \mathrm{l}$ containing $67 \mathrm{~mm}$-phosphate buffer ( $\mathrm{pH} 7), 1$ mM-EDTA and $20 \mathrm{~mm}-\mathrm{H}_{2} \mathrm{O}_{2}$. Activity was determined by following the reduction of $\mathrm{H}_{2} \mathrm{O}_{2}$ at $30^{\circ} \mathrm{C}$ and $240 \mathrm{~nm}$ using the extinction coefficient $40 \mathrm{M}^{-1} / \mathrm{cm}^{(21)}$. One unit of CAT represents the amount of enzyme that decomposes $1 \mu \mathrm{mol} \mathrm{H}_{2} \mathrm{O}_{2}$ per min.

GPX activity (EC 1.11.1.9) was assayed by following the rate of NADPH oxidation at $340 \mathrm{~nm}$ and $30^{\circ} \mathrm{C}$ by the coupled reaction with glutathione reductase using the extinction coefficient $6.22 \mathrm{mM}^{-1} / \mathrm{cm}^{(22)}$. Cumene hydroperoxide and $\mathrm{H}_{2} \mathrm{O}_{2}$ were the substrates for measuring total GPX and Se-dependent GPX (Se-GPX), respectively. The assay was realised in a microplate with $20 \mu \mathrm{l}$ sample solution in a final volume of $240 \mu \mathrm{l}$ containing $50 \mathrm{~mm}$-phosphate buffer (pH 7.4), 1 mM-EDTA, 2 mMsodium azide, $2 \mathrm{~mm}$-reduced glutathione, $0 \cdot 1 \mathrm{~mm}-\mathrm{NADPH}$, 0.2 units glutathione reductase and $0.2 \mathrm{mM}$-cumene hydroperoxide or $50 \mu \mathrm{M}-\mathrm{H}_{2} \mathrm{O}_{2}$. One unit of GPX is defined as the amount of enzyme that catalyses the oxidation of $1 \mu \mathrm{mol}$ NADPH per min.

Protein concentration was determined according to Lowry et al. ${ }^{(23)}$, using bovine serum albumin as a standard.

\section{Design of polymerase chain reaction primers and probes}

PCR primers used for the quantification of the different genes were designed using Primer 3 software (Table 3). The cDNA sequences of the elongation factor $1 \alpha(\mathrm{EF} 1 \alpha)$ and the cytosolic $\mathrm{Cu} / \mathrm{Zn}$ superoxide dismutase (SOD1) were obtained from GenBank sequences AF498320 and AF469663, respectively. The cDNA sequences of CAT, mitochondrial Mn superoxide dismutase (SOD2), phospholipid-hydroperoxide glutathione peroxidase (HPGPX) and cytosolic glutathione peroxidase (GPX1) were obtained from The Institute for Genomic Research (TIGR) sequences TC99600, TC104653, TC95828 and TC126469, respectively. The PCR products were run on a $2 \%$ agarose gel to check that only one fragment was amplified (i.e. absence of genomic DNA amplification) and sequenced to ensure that the correct mRNA sequences were quantified.

\section{Real-time quantitative reverse transcriptase-polymerase chain} reaction

Total RNA was extracted from embryos and larvae using Trizol reagent (Invitrogen, Cergy-Pontoise, France) according to the manufacturer's instructions, and stored in nuclease-free water (Promega, Charbonnières, France). Genomic DNA was eliminated from the samples using RQ1 Rnase-Free DNase (Promega) and purified RNA was then stored at $-20^{\circ} \mathrm{C}$. Samples were subjected to electrophoresis on $1 \%$ agarose gels to confirm the integrity of the $28 \mathrm{~S}$ and $18 \mathrm{~S}$ rRNA bands and RNA quality was assessed as the 260:280 nm absorbance ratio.

cDNA was generated from $1 \mu \mathrm{g}$ DNase-treated total RNA using $200 \mathrm{U}$ SuperSript ${ }^{\mathrm{TM}}$ III RT (Invitrogen) and $500 \mathrm{ng}$ oligo(dT) 15 primers (Promega) in a total volume of $20 \mu$ l. The thermal cycle used for RNA samples was: $65^{\circ} \mathrm{C}$ for $3 \mathrm{~min}$, $25^{\circ} \mathrm{C}$ for $10 \mathrm{~min}, 42^{\circ} \mathrm{C}$ for $1 \mathrm{~h}$ and then $99^{\circ} \mathrm{C}$ for $5 \mathrm{~min}$. For each sample, reverse transcription was performed in duplicate.

Real-time PCR was performed using the $\mathrm{iCycler}^{\mathrm{iQ}} \mathrm{Q}^{\mathrm{TM}}$ (BioRad, Marnes-la-Coquette, France) with $\mathrm{iQ}^{\mathrm{TM}} \mathrm{SYBR}^{\circledR}$ Green Supermix (Bio-Rad). All PCR reactions were set up in ninety-six-well plates using $200 \mathrm{nmol} / \mathrm{l}$ of each primer and $10 \mu \mathrm{l}$ cDNA (dilution factor $=32$ ) in a reaction volume of $25 \mu \mathrm{l}$. Thermal cycling was initiated with incubation at $95^{\circ} \mathrm{C}$ for $3 \mathrm{~min}$ for hot-start $\mathrm{iTaq}^{\mathrm{TM}}$ DNA polymerase activation. Thirty-five steps of PCR were performed, each one consisting of heating at $95^{\circ} \mathrm{C}$ for $20 \mathrm{~s}$ and at the annealing temperature for 30 s (Table 3). Following the final cycle of the PCR, melting curves were systematically monitored (increase set point temperature from 55 to $94^{\circ} \mathrm{C}$ by $0.5^{\circ} \mathrm{C} / 10 \mathrm{~s}$ ) to confirm production of a single product. Each cDNA sample was assayed in duplicate. Controls were included in each plate to test the absence of contamination by genomic DNA or assay reagents. Standard curves were obtained for each cDNA template by plotting the cycle threshold (CT) values against the $\log _{10}$ of five different dilutions (in triplicate) of cDNA sample solutions. CT values corresponded to the number of cycles at which the fluorescence emission monitored in real-time exceeded the threshold limit.

Real-time amplification PCR efficiency was determined from standard curves according to $\mathrm{E}=10^{(-1 / \text { slope })}$. The relative expression ratio $(\mathrm{R})$ of each target gene was calculated based on PCR efficiency and CT deviation between sample

Table 3. Sequences of the polymerase chain reaction primers used to assay gene expression by real-time quantitative polymerase chain reaction

\begin{tabular}{|c|c|c|c|c|}
\hline Gene & Forward primer & Reverse primer & Product size (bp) & Annealing temperature $\left({ }^{\circ} \mathrm{C}\right)$ \\
\hline $\mathrm{EF} 1 \alpha$ & TCCTCTTGGTCGTTTCGCTG & ACCCGAGGGACATCCTGTG & 159 & 59 \\
\hline SOD1 & TGGTCCTGTGAAGCTGATTG & TTGTCAGCTCCTGCAGTCAC & 201 & 56 \\
\hline SOD2 & TCCCTGACCTGACCTACGAC & GGCCTCCTCCATTAAACCTC & 201 & $56 \cdot 5$ \\
\hline CAT & TGATGTCACACAGGTGCGTA & GTGGGCTCAGTGTTGTTGAG & 195 & 55 \\
\hline GPX1 & CGAGCTCCATGAACGGTACG & TGCTTCCCGTTCACATCCAC & 183 & 59 \\
\hline HPGPX & TTGGAGGTCAGGAGCCAGGT & ACCCTTTCCCTTGGGCTGTT & 152 & 59 \\
\hline
\end{tabular}

EF1 $\alpha$, elongation factor $1 \alpha$; SOD, superoxide dismutase; CAT, catalase; GPX, glutathione peroxidase; HPGPX, phospholipid-hydroperoxide glutathione peroxidase. 
and control using the Relative Expression Software Tool $(\mathrm{REST} C)^{(24)}$. R was expressed in comparison with normalised EF1 $\alpha$ as the reference gene according to Essex-Fraser et al. ${ }^{(25)}$ as no reference gene $(\mathrm{EF} 1 \alpha, \beta$-actin and glyceraldehyde3 -phosphate dehydrogenase) could be used directly. The level expression of EF1 $\alpha$ within each group was normalised to a selected control group $(70 \mathrm{dpf})$ as follows: individual value within a group/(mean value within a group/mean value of control group). The swim-up fry stage was chosen as the control as the mean CT value of this group was close to the mean CT value of all samples for EF1 $\alpha$.

\section{Statistical analyses}

Results are given as mean values and standard deviations. Statistical analyses were performed with the computing program Statbox (Grimmer Logiciels, Paris, France) and differences were considered significant when $P$ values were $<0 \cdot 05$. Statistical differences in gene expression between the control group and samples were evaluated in group means by 5000 randomisation tests using REST software ${ }^{(24)}$ and differences were considered significant at $P<0 \cdot 05$.

\section{Results}

\section{Growth performance}

Fertilisation rate was very good $(96.6 \%)$ and survival remained high from the eyed stage (32 dpf) onwards (Table 4). Mean wet weight increased about 20 -fold from the oocyte stage to the 2-month-fed fry stage. No significant differences of survival or growth were observed between fry fed $\mathrm{CO}$ and fry fed OX.

\section{Levels of lipid peroxidation products}

The levels of 8-isoprostane were the highest in oocytes but no significant effect of dietary oxidised lipid was recorded (Table 5). On the other hand, the levels of LSFP were consistently higher in fry fed OX than in fry fed $\mathrm{CO}$ for a given stage. No clear effect of fry development on the evolution of these products of lipid peroxidation was noted.

\section{Retinoid contents in oocytes and fry}

Retinoic acid was found to be higher in oocytes than in fry; it decreased during development and by 2 months was higher in fry fed $\mathrm{CO}$ than in fry fed OX (Table 6). Like retinoic acid, retinol was in higher concentrations in oocytes than in fry. It decreased during development and was significantly lower in 2-month fry fed OX compared with fry fed CO. Retinal contents decreased in 2-month fry fed OX but trends during development were less clear. Retinyl palmitate appeared to be the main storage form of vitamin A in oocytes and fry, except in fry fed OX. It decreased during development and was significantly lower in 2-month fry fed OX compared with fry fed CO.

\section{Antioxidant enzymes}

SOD activity was detectable in $21 \mathrm{dpf}$ embryos (Fig. 1(A)). It increased slowly during development but no significant

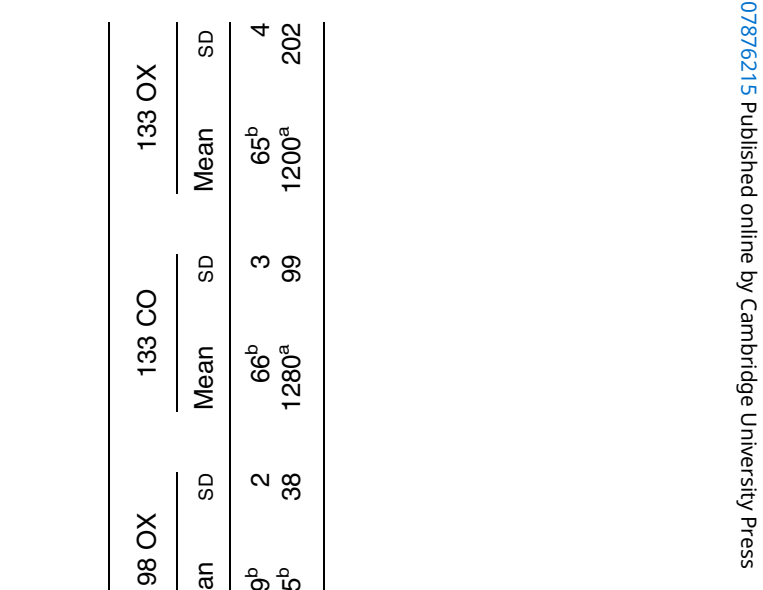


difference was observed according to fry diet. SOD1 and SOD2 genes were expressed from $21 \mathrm{dpf}$ embryos to 2-months-fed fry (Figs. 2(A) and (B)). SOD1 gene expression was not significantly different during development except for 1-month and 2-month fry fed OX where an increase was noted. SOD1 gene expression was significantly higher in fry fed OX than in fry fed CO (1.29-, 1.31- and 1.35-fold for 81,98 and $133 \mathrm{dpf}$ fry). SOD2 gene expression increased during development particularly during the early stages of development ( 21 and $44 \mathrm{dpf}$ ) and this expression was significantly higher (1.30-fold) in 2-month fry fed OX than in 2-month fry fed $\mathrm{CO}$.

CAT activity, which was not detectable in $21 \mathrm{dpf}$ embryos, greatly increased during development particularly after 2-month feeding (Fig. 1(B)). This activity was affected by dietary levels of oxidised lipid: 2-month fry fed OX showed a higher activity than fry fed CO. CAT gene expression was detectable in $21 \mathrm{dpf}$ embryos with an expression significantly higher than in newly hatched fry. CAT gene expression increased during development from hatching to 2-month-fed fry (Fig. 2(C)). This expression was significantly higher (1.33-fold) in 1-month fry fed OX than in 1-month fry fed CO.

Among GPX, Se-GPX activity was higher than non-SeGPX activity (Figs. 1(C) and (D)). Non-Se-GPX activity was detectable from $70 \mathrm{dpf}$ and stayed low, without significant difference among dietary groups. However, Se-GPX activity was detectable from hatching and increased during development. Two Se-GPX were studied by RT-PCR: HPGPX and GPX1 (Figs. 2(D) and (E)). HPGPX mRNA abundance was more or less constant during development. It was significantly higher at the $21 \mathrm{dpf}$ stage and 2-month fry fed OX. The HPGPX gene was 1.31-fold more expressed in fry fed OX than in fry fed $\mathrm{CO}$ after 1 month of feeding. GPX1 gene expression decreased from $21 \mathrm{dpf}$ to hatching before increasing significantly from the swim-up stage to the end of the experiment. The GPX1 gene was 1.32-fold more expressed in fry fed OX than in fry fed $\mathrm{CO}$ after 2 months of feeding.

\section{Discussion}

\section{Evolution of antioxidant defences during larval development}

The present results show that both the activity and expression of genes coding for antioxidant enzymes increased during rainbow trout development. The evolution of the three antioxidant enzymes SOD, CAT and GPX confirm previous results obtained by Aceto et al. ${ }^{(26)}$ in rainbow trout embryos. The same tendencies have also been reported for CAT and GPX in other fish species such as turbot ${ }^{(27)}$ and common dentex $^{(28)}$ whereas the reverse has been observed for SOD. However, the present study has shown that only SOD presented a readily measurable activity in embryos, which seems to confirm that like in turbot and common dentex, SOD is needed in the very early developmental stages to reduce elevated tissue concentration of $\mathrm{O}_{2}^{-(27)}$. According to Vernier $^{(29)}$, kidney and liver are present at the rainbow trout embryonic stage analysed in the present study and SOD has been reported to be highly active in these two tissues ${ }^{(26)}$.

The present study is the first one to measure the expression of genes coding for antioxidant enzymes during the early 
Table 6. Levels of different retinoids in rainbow trout (Oncorhynchus mykiss) oocytes and fry (ng/g) (Mean values and standard deviations of three replicates)

\begin{tabular}{|c|c|c|c|c|c|c|c|c|c|c|c|c|}
\hline \multirow[b]{2}{*}{ Stage (dpf) } & \multicolumn{2}{|c|}{0} & \multicolumn{2}{|c|}{70} & \multicolumn{2}{|c|}{$98 \mathrm{CO}$} & \multicolumn{2}{|c|}{98 OX } & \multicolumn{2}{|c|}{$133 \mathrm{CO}$} & \multicolumn{2}{|c|}{$133 \mathrm{OX}$} \\
\hline & Mean & SD & Mean & SD & Mean & SD & Mean & SD & Mean & SD & Mean & SD \\
\hline Retinoic acid & $213^{a}$ & 21 & $191^{a}$ & 38 & $17^{\mathrm{b}}$ & 8 & $22^{\mathrm{b}}$ & 12 & $11^{\mathrm{b}}$ & 3 & $1^{c}$ & \\
\hline Retinol & $1893^{\mathrm{a}}$ & 77 & $502^{b}$ & 84 & $206^{c, d}$ & 10 & $315^{\mathrm{c}}$ & 111 & $134^{\mathrm{d}, \mathrm{e}}$ & 51 & $24^{e}$ & 12 \\
\hline Retinal & $116^{a, b}$ & 21 & $136^{a, b}$ & 19 & $5^{c}$ & 5 & $23^{\mathrm{C}}$ & 30 & $315^{\mathrm{a}}$ & 61 & $50^{b}$ & 18 \\
\hline Retinyl palmitate & $48463^{a}$ & 7866 & $5785^{\mathrm{b}}$ & 458 & $181^{\mathrm{c}}$ & 37 & $327^{c}$ & 200 & $517^{\mathrm{c}}$ & 422 & $15^{\mathrm{d}}$ & \\
\hline
\end{tabular}

dpf, Days post-fertilisation; CO, semi-purified diet with $0 \%$ oxidised lipid; OX, semi-purified diet with $8 \%$ oxidised lipid.

${ }^{a-e}$ Mean values within a row with unlike superscript letters are significantly different $(P<0.05)$.

development of fish. The results of gene expression analyses confirm data of antioxidant enzyme activities. The increase of SOD2 gene expression occurred during the very early stages, between the embryo and swim-up stages, whereas the increases of CAT and GPX1 gene expression were noted later, between hatching and complete yolk-sac resorption. All studied genes coding for antioxidant enzymes have been shown to be expressed from the embryonic stage. The genes coding for HPGPX and GPX1 were even more expressed in rainbow trout embryos compared with swim-up fry.

Contrary to antioxidant enzymes, retinoids declined during rainbow trout early development. A decrease of retinol during embryonic development has also been reported for lake trout ${ }^{(30)}$. This pattern in fish larval stages is similar to what has been described for other antioxidant vitamins such as vitamin $\mathrm{E}^{(12,28)}$. These non-enzymic antioxidants in fish eggs are essential to ensure early antioxidant protection.
However, retinoids, especially retinoic acids, are also recognised as highly active molecules in developmental processes $^{(31)}$. In higher vertebrate cells, retinoic acids exist in several stereoisomeric forms: predominantly all-trans-retinoic acid and 13-cis-retinoic acid, but also as less-stable isomers such as 9-cis-retinoic acid $^{(32)}$. In the present study, 9-cis-retinoic acid was not detected in any of the developmental stages and 13-cis-retinoic acid was detected only in fry and in very low amounts (data not shown). As in higher vertebrates, all-trans-retinoic acid was the main form of retinoic acid in rainbow trout oocytes and fry. Oocytes displayed significant levels of retinoic acid and these levels declined during embryonic development. Retinyl palmitate was the major retinoid in rainbow trout oocytes and fry with levels ranging from $44 \%$ in fry fed diet CO to $96 \%$ in oocytes. Retinal was reported to be the essential mode of retinoid storage in eggs of teleosts whereas retinyl esters were described as
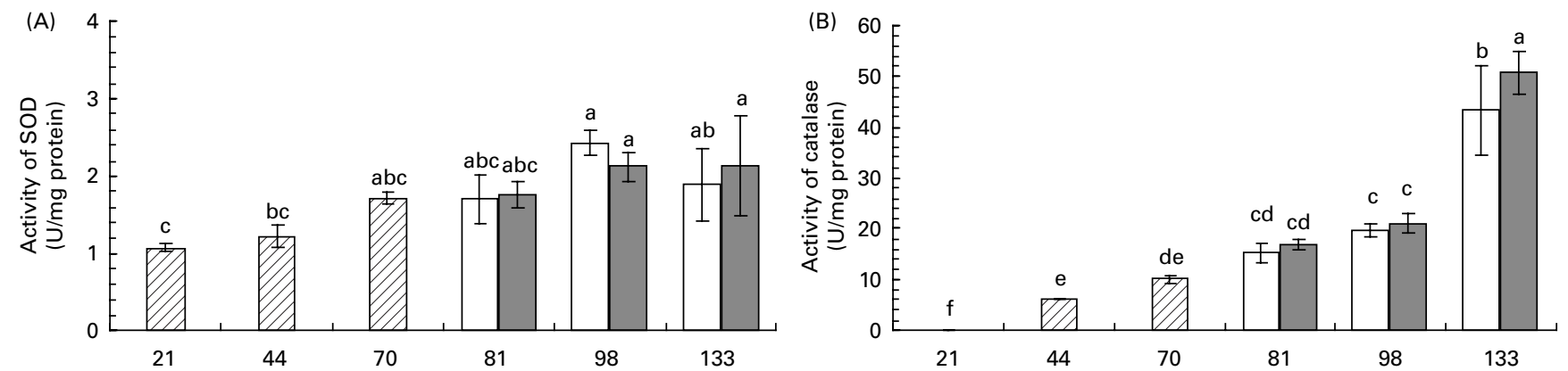

(C)

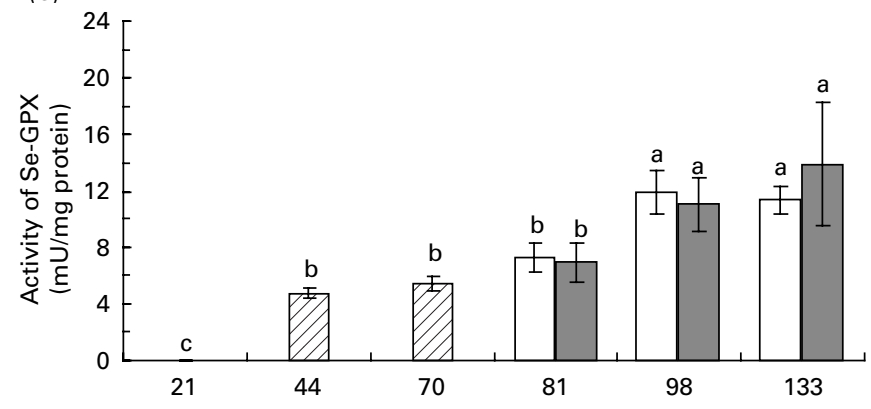

(D)

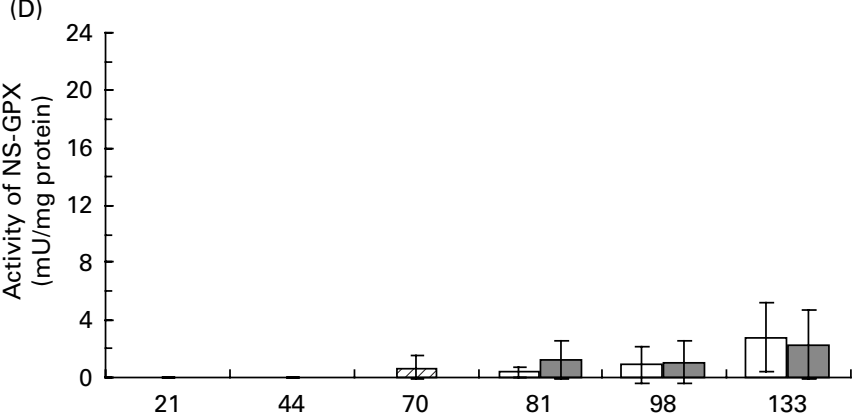

Days post-fertilisation

Fig. 1. Activity of superoxide dismutase (SOD) (A), catalase (B), Se-dependent glutathione peroxidase (Se-GPX) (C) and non-Se-GPX (NS-GPX) (D) in rainbow trout (Oncorhynchus mykiss) embryos and fry fed different diets: ( $\square$ ) before exogenous feeding; ( $\square$ ) fry fed semi-purified diet with $0 \%$ oxidised lipid; ( $\square$ ) fry fed semi-purified diet with $8 \%$ oxidised lipid. Values are means $(n 3)$, with standard deviations represented by vertical bars. ${ }^{a, b, c, d}$ Mean values with unlike letters are significantly different $(P<0.05)$. 

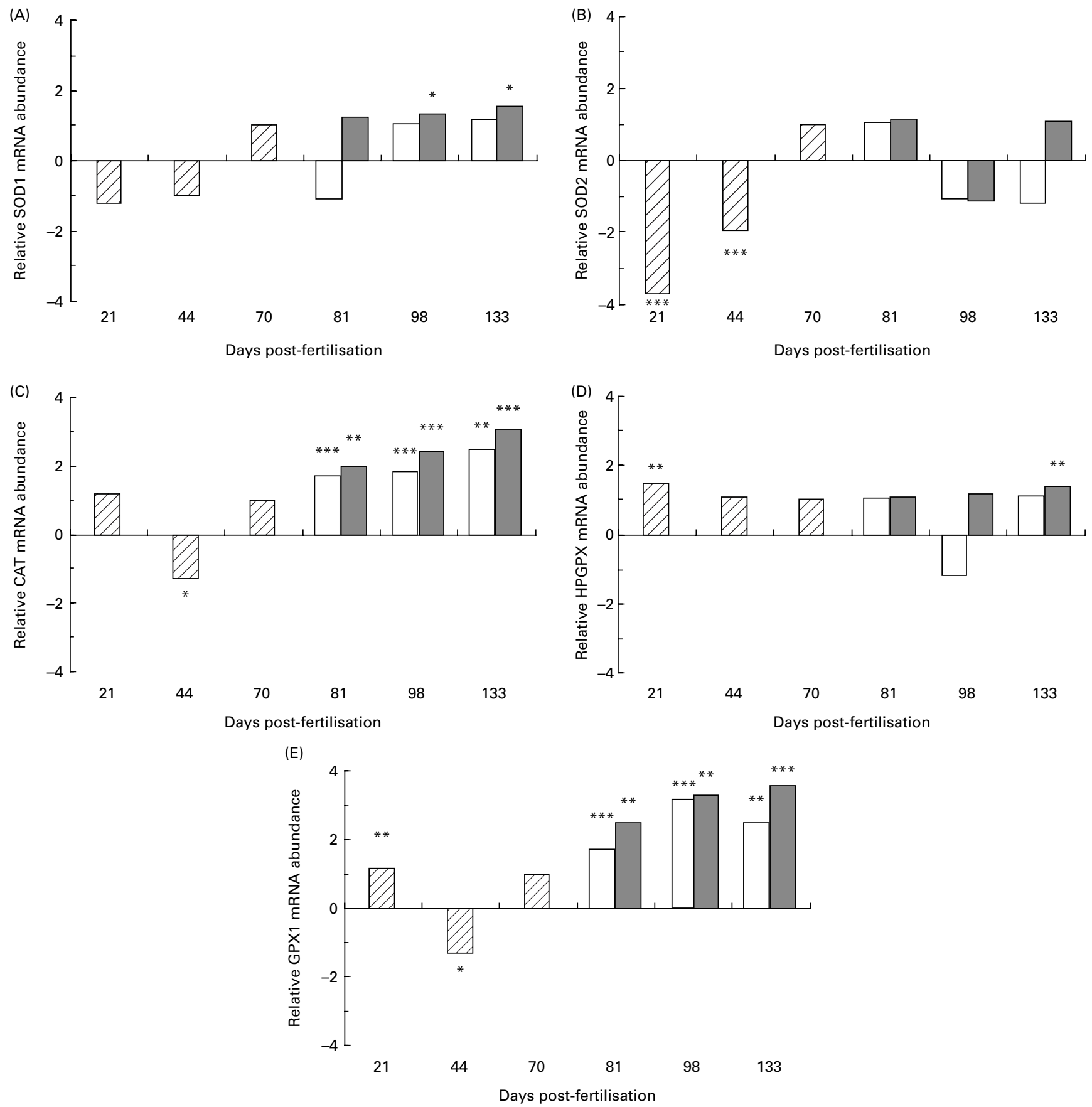

Fig. 2. Relative expression of superoxide dismutase-1 (SOD1) (A), SOD2 (B), catalase (CAT) (C), phospholipid-hydroperoxide glutathione peroxidase (HPGPX) (D) and glutathione peroxidase-1 (GPX1) (E) genes normalised with elongation factor $1 \alpha$ in rainbow trout (Oncorhynchus mykiss) embryos and fry fed different diets: $(\square)$ before exogenous feeding; $(\square)$ fry fed semi-purified diet with $0 \%$ oxidised lipid; $(\square)$ fry fed semi-purified diet with $8 \%$ oxidised lipid. Mean value was significantly different from that of the control group, the swim-up fry stage (70 days post-fertilisation): ${ }^{*} P<0.05,{ }^{\star \star} P<0.01,{ }^{\star \star \star} P<0.001$.

additional retinoids that accompany the accumulation of lipid substances $^{(33)}$. In the present study, total lipid accounted for $12 \%$ of oocyte wet weight and $4 \%$ of 2 -month fry wet weight and could not explain totally the observed difference between the present results with very low levels of retinal in oocytes (about $0.2 \%$ of total retinoids) and the results obtained on Chum salmon eggs by Irie \& Seki ${ }^{(34)}$. The high levels of retinol and retinyl palmitate in rainbow trout oocytes could ensure the early antioxidant protection by stabilising peroxyl radicals produced in the developing embryo as suggested by Palace \& Werner ${ }^{(12)}$.

\section{Response of antioxidant defences to dietary oxidised lipid}

Feeding rainbow trout fry with oxidised lipid resulted in decreased vitamin A larval contents and increased levels of lipid peroxidation products as well as increased antioxidant enzyme activity and gene expression. However, fry fed oxidised 
lipid did not display any significant decrease of growth or survival compared with fry fed the control diet in agreement with what has been reported in juvenile rainbow trout ${ }^{(35,36)}$, European sea bass ${ }^{(37)}$, gilthead sea bream ${ }^{(38)}$ and Atlantic halibut ${ }^{(39)}$. In the last study, some skeletal malformations were noticed. Other malformations such as muscular dystrophy or 'Sekoke' disease have been reported in juvenile common carp and Siberian sturgeon larvae fed oxidised lipid ${ }^{(7,19)}$. In the present study, no obvious malformation was evidenced whereas the same level and degree of oxidised lipid as in our previous study ${ }^{(19)}$ with Siberian sturgeon larvae were tested. So, according to growth performance and response of antioxidant defences, rainbow trout fry fed oxidised lipid displayed a moderate oxidative stress. No deleterious effect was noted probably due to the clear response of the enzyme-dependent antioxidant defence system at the molecular level. Also Tocher et al. ${ }^{(40)}$ showed in three marine species that the extent of peroxidative stress and deleterious effects appeared inversely proportional to the responses of hepatic antioxidant defence enzyme activities.

In the present study, among antioxidant enzymes, CAT displayed the most pronounced increase of activity after 2 months of feeding with dietary oxidised lipid. The increase in gene expression occurred earlier, after 1 month of feeding. The response of other antioxidant enzymes to dietary oxidised lipid was noticed at the molecular level with an increase in gene expression as soon as $11 \mathrm{~d}$ feeding for cytosolic $\mathrm{Cu} / \mathrm{Zn}$ SOD and 2 months of feeding for GPX1. The gene expression analysis of the two SOD isoforms revealed that SOD1 was more sensitive to dietary oxidised lipid than SOD2. The mRNA levels of antioxidant enzymes constitute a valid biomarker of oxidative stress as suggested by Olsvik et al. ${ }^{(41)}$.

Levels of lipid peroxidation products such as LSFP and 8-isoprostane positively correlated to antioxidant enzyme activities and gene expression and negatively correlated to retinoid levels. However, a high level of 8-isoprostane was found in oocytes compared with fry whereas no significant difference of LSFP was noted between oocytes and fry. This discrepancy between results could be due to an overestimation of isoprostanes in oocytes, which then masked significant differences between fry groups. Lipid peroxidation is difficult to evaluate and since none of the different analytical methods taken individually is ideal ${ }^{(2)}$, the use of a combination of different measurements is preferable.

In conclusion, the present results suggest that rainbow trout fry antioxidant defence systems are active all through development with a predominance of antioxidant vitamins in the earliest stages and then a predominance of antioxidant enzymes. The antioxidant defence systems can be modulated by feeding oxidised lipid. The activation of antioxidant enzymes and the use of antioxidant vitamins such as vitamin A to eliminate free radicals in rainbow trout fry allow counteraction in part of the oxidative stress which can be then described as moderate. Dietary oxidised lipid resulted in increased levels of larval lipid peroxidation products leading to a decrease a flesh quality, but no depression of growth or survival or high occurrence of deformed fish was recorded.

\section{Acknowledgements}

The present study was supported in part by Action Incitative INRA-IFREMER.
S. F. designed the research with advice from S. K.; E. L. and J. B. performed the research and contributed new analytical tools; S. F., E. L. and J. B. analysed the data; S. F., E. L. and J. B. wrote the paper and S. K. revised it.

The authors wish to thank La Lorientaise (Lorient, France) for the kind supply of salmon oil without any antioxidant. They are very grateful to P. Aguirre, P. Maunas, J.-P. Fouriot, F. Terrier, F. Sandres and Y. Hontang for the preparation of larval diets and care of fish. Due acknowledgements are also made to M.-J. Borthaire, C. Vachot, S. Berhonde, G. Beyries and S. Huguenard for their technical assistance and S. Panserat and E. Plagnes-Juan for advice in gene expression analysis.

There is no conflict of interest that the authors should disclose.

\section{References}

1. Fridovich I (1998) Oxygen toxicity: a radical explanation. $J$ Exp Biol 201, 1203-1209.

2. Halliwell B \& Gutteridge JMC (2007) Free Radicals in Biology and Medicine, 4th ed., Oxford: Oxford University Press.

3. Hsieh RJ \& Kinsella JE (1989) Oxidation of polyunsaturated fatty acids: mechanisms, products, and inhibition with emphasis on fish. Adv Food Nutr Res 33, 233-341.

4. Watanabe T \& Hashimoto Y (1968) Toxic components of oxidized saury oil inducing muscular dystrophy in carp. Bull Jpn Soc Sci Fish 34, 1131-1140.

5. Hata K, Fujimoto K \& Kaneda T (1986) Absorption of lipid hydroperoxides in carp. Bull Jpn Soc Sci Fish 52, 677-684.

6. Sargent JR, Tocher DR \& Bell JG (2002) The lipids. In Fish Nutrition, 3rd ed. pp. 182-259 [JE Halver and RW Hardy, editors]. London: Academic Press.

7. Hata K \& Kaneda T (1980) Effect of autoxidized oil on carp. Bull Jpn Soc Sci Fish 46, 997-1000.

8. Fridovich I (1997) Superoxide anion radical $\left(\mathrm{O}_{2}^{-}\right)$, superoxide dismutases, and related matters. J Biol Chem 272, 18515-18517.

9. Palacios A, Piergiacomi VA \& Catala A (1996) Vitamin A supplementation inhibits chemiluminescence and lipid peroxidation in isolated rat liver microsomes and mitochondria. Mol Cell Biochem 154, 77-82.

10. Palace VP, Khaper N, Qin QI \& Singal PK (1999) Antioxidant potentials of vitamin A and carotenoids and their relevance to heart disease. Free Radic Biol Med 26, 746-761.

11. Ahlemeyer B, Bauerbach E, Plath M, Steuber M, Heers C, Tegtmeier F \& Krieglstein J (2001) Retinoic acid reduces apoptosis and oxidative stress by preservation of SOD protein level. Free Radic Biol Med 30, 1067-1077.

12. Palace VP \& Werner J (2006) Vitamins A and E in the maternal diet influence egg quality and early life stage development in fish: a review. Sci Mar 70S2, 41-57.

13. Folch J, Lees M \& Sloane Stanley GH (1957) A simple method for the isolation and purification of total lipides from animal tissues. J Biol Chem 226, 497-509.

14. Shantha NC \& Ackman RG (1990) Nervonic acid versus tricosanoic acid as internal standards in quantitative gas chromatographic analyses of fish oil longer-chain $n-3$ polyunsaturated fatty acid methyl esters. J Chromatogr 533, 1-10.

15. Shantha NC \& Decker EA (1994) Rapid, sensitive, iron-based spectrophotometric methods for determination of peroxide values of food lipids. J AOAC Int 77, 421-424.

16. European Committee for Standardization (2002) Animal and Vegetable Fats and Oils - Determination of Ultraviolet Absorbance Expressed as Specific UV Extinction. ISO 3656:2002. Brussels: CEN. 
17. European Committee for Standardization (2000) Animal and Vegetable Fats and Oils - Determination of Anisidine Value. ISO 6885:2000. Brussels: CEN.

18. Salih AM, Smith DM, Price JF \& Dawson LE (1987) Modified extraction 2-thiobarbituric acid method for measuring lipid oxidation in poultry. Poult Sci 66, 1483-1488.

19. Fontagné $\mathrm{S}$, Bazin $\mathrm{D}$, Brèque $\mathrm{J}$, Vachot $\mathrm{C}$, Bernarde $\mathrm{C}$, Rouault $\mathrm{T}$ \& Bergot $P$ (2006) Effects of dietary oxidized lipid and vitamin A on the early development and antioxidant status of Siberian sturgeon (Acipenser baeri) larvae. Aquaculture 257, 400-411.

20. Ukeda H, Kawana D, Maeda S \& Sawamura M (1999) Spectrophotometric assay for superoxide dismutase based on the reduction of highly water-soluble tetrazolium salts by xanthinexanthine oxidase. Biosci Biotechnol Biochem 63, 485-488.

21. Beers RF \& Sizer IW (1952) Spectrophotometric method for measuring the breakdown of hydrogen peroxide by catalase. $J$ Biol Chem 195, 133-140.

22. Bell JG, Cowey CB, Adron JW \& Shanks AM (1985) Some effects of vitamin $\mathrm{E}$ and selenium deprivation on tissue enzyme levels and indices of tissue peroxidation in rainbow trout (Salmo gairdneri). Br J Nutr 53, 149-157.

23. Lowry OH, Rosebrough NJ, Farr AL \& Randall RJ (1951) Protein measurement with the Folin-phenol reagent. J Biol Chem 193, 265-275.

24. Pfaffl MW, Horgan GW \& Dempfle L (2002) Relative expression software tool (RESTC) for group-wise comparison and statistical analysis of relative expression results in realtime PCR. Nucl Acids Res 30, e36.

25. Essex-Fraser PA, Steele SL, Bernier NJ, Murray BW, Stevens ED \& Wright PA (2005) Expression of four glutamine synthetase genes in the early stages of development of rainbow trout (Oncorhynchus mykiss) in relationship to nitrogen excretion. $J$ Biol Chem 280, 20268-20273.

26. Aceto A, Amicarelli F, Sacchetta P, Dragani B, Bucciarelli T, Masciocco L, Miranda M \& Di Ilio C (1994) Developmental aspects of detoxifying enzymes in fish (Salmo iridaeus). Free Radic Res 21, 285-294.

27. Peters LD \& Livingstone DR (1996) Antioxidant enzyme activities in embryologic and early larval stages of turbot. J Fish Biol 49, 986-997.

28. Mourente G, Tocher DR, Diaz E, Grau A \& Pastor E (1999) Relationships between antioxidants, antioxidant enzyme activities and lipid peroxidation products during early development in Dentex dentex eggs and larvae. Aquaculture 179, 309-324.

29. Vernier JM (1969) Table chronologique du développement embryonnaire de la truite arc-en-ciel, Salmo gairdneri Rich. 1836 (Chronological table of embyonic development of rainbow trout, Salmo gairdneri Rich. 1836). Ann Embryol Morph 2, $495-520$.
30. Palace VP, Brown SB, Baron CL, Fitzsimons J, Woodin B, Stegeman JJ \& Klaverkamp JF (1998) An evaluation of the relationships among oxidative stress, antioxidant vitamins and early mortality syndrome (EMS) of lake trout (Salvelinus namaycush) from Lake Ontario. Aquat Toxicol 43, 195-208.

31. Zile MH (1998) Vitamin A and embryonic development: an overview. J Nutr 128, 455S-458S.

32. Armstrong JL, Redfern CPF \& Veal GJ (2005) 13-cis Retinoic acid and isomerisation in paediatric oncology - is changing shape the key to success? Biochem Pharmacol 69, 1299-1306.

33. Rühl R, Plum C, Elmazar MMA \& Nau H (2001) Embryonic subcellular distribution of 13-cis- and all-trans-retinoic acid indicates differential cytosolic/nuclear localization. Toxicol Sci 63, 82-89.

34. Irie T \& Seki T (2002) Retinoid composition and retinal localization in the eggs of teleost fishes. Comp Biochem Physiol 131B, 209-219.

35. Hung SSO, Cho CY \& Slinger SJ (1981) Effect of oxidized fish oil, DL- $\alpha$-tocopheryl acetate and ethoxyquin supplementation on the vitamin E nutrition of rainbow trout (Salmo gairdneri) fed practical diets. J Nutr 111, 648-654.

36. Cowey CB, Degener E, Tacon AGJ, Youngson A \& Bell JG (1984) The effect of vitamin E and oxidised fish oil on the nutrition of rainbow trout (Salmo gairdneri) grown at natural, varying water temperatures. Br J Nutr 51, 443-451.

37. Messager JL, Stephan G, Quentel C \& Baudin Laurencin F (1992) Effects of dietary oxidized fish oil and antioxidant deficiency on histopathology, haematology, tissue and plasma biochemistry of sea bass Dicentrarchus labrax. Aquat Living Resour 5, 205-214.

38. Mourente G, Diaz-Salvago E, Bell JG \& Tocher DR (2002) Increased activities of hepatic antioxidant defence enzymes in juvenile gilthead sea bream (Sparus aurata L.) fed dietary oxidised oil: attenuation by dietary vitamin E. Aquaculture 214, $343-361$

39. Lewis-McCrea LM \& Lall SP (2007) Effects of moderately oxidized dietary lipid and the role of vitamin $\mathrm{E}$ on the development of skeletal abnormalities in juvenile Atlantic halibut (Hippoglossus hippoglossus). Aquaculture 262, 142-155.

40. Tocher DR, Mourente G, Van der Eecken A, Evjemo JO, Diaz E, Wille M, Bell JG \& Olsen Y (2003) Comparative study of antioxidant defence mechanisms in marine fish fed variable levels of oxidised oil and vitamin E. Aquacult Int 11, 195-216.

41. Olsvik PA, Kristensen T, Waagb $\varnothing$ R, Rosseland BO, Tollefsen K-E, Baeverfjord G \& Berntssen MHG (2005) mRNA expression of antioxidant enzymes (SOD, CAT and GSH-Px) and lipid peroxidative stress in liver of Atlantic salmon (Salmo salar) exposed to hyperoxic water during smoltification. Comp Biochem Physiol 141C, 314-323. 